Reviews

responsible must not attempt to legislate responsibility via agenda, but instead must engage in sincere dialogue with cultural representatives to gain necessary social knowledge. The chapter is useful, however, as a way of contrasting agenda-driven social responsibility claims with more culturally interpretive strategies described in Chapters 5 and 6. Reeves-Ellington recounts his experiences as operations vice-president of a multinational pharmaceutical company he calls "Pharmco." His story in Chapter 6 describing his involvement in a problematic purchase of land in a Javanese farming community is both interesting and illustrative. Successful completion of the deal demanded accommodations to local circumstances and values that likely would send most companies looking elsewhere for a less complicated situation. Stylistically, it is a testament to the power of storytelling that this chapter is so much more engaging and satisfying than the first two.

The final chapter, "Beyond Agenda," is the richest and most informative section of the book. In fact, I recommend starting with the preface, skipping to Chapter 7, then returning to Chapter 1 and subsequent chapters. Here the authors provide a good summary of their argument, and offer a valuably reflexive set of alternative interpretations of central conclusions made regarding the Pharmco land purchase. This exercise is both courageous and an excellent example of the openness to competing explanations that is fundamental to their social responsibility thesis.

With increasing publications of books arguing for corporate social responsibility, I question the marketing strategy behind the design of this work. As textbook or graduate seminar reader the line of argument and learning objectives are too opaque. As popular business book, theoretical sections are unappealingly dense and singular focus on broad international implications of CSR is restrictive. A general business audience would ask for at least minimal discussion of CSR issues specifically related to human resources, investors, or financial incentives. This book falls uncomfortably between genre, but valuable observations are available to the adventurous.

\title{
Which Home Do We Protect? The Challenge of Protecting Endangered Species and Property. A Review Essay on Private Property and the Endangered Species Act, edited by Jason F. Shogren. (1998). Austin: University of Texas Press. xv, 153 pp.
}

\section{Reviewed by Richard Castelnuovo, College of Agricultural and Life Sciences, University of Wisconsin.}

As much as any part of our heritage, private property defines who we are as Americans. It is an organizing principle for our government and cultural symbol of our independence and freedom (Salamon, 1998: 175-6). Environmental laws challenge concepts of private property, imposing land use and other restrictions on private choice for the benefit of the public. No environmental law has had a more direct impact on private property than the Endangered Species Act (ESA). In turn, property rights have significantly influenced the course of the ESA and the fate of the species it protects. In the name of private property, individual landowners have raised the battle cry of "shoot, shovel and shut up" and destroyed species and critical habit to evade the law's reach (Van de Werf, 1995: B1). Using legitimate channels, they have mobilized to apply effective political pressure to change the law and its administration. Ultimately this controversy between the protection of property and the environment has transformed the ESA into one of the most 


\section{Reviews}

innovative environmental laws, providing for flexible species protection through Habitat Conservation Plans (HCPs).

Private Property and the Endangered Species Act (University of Texas, 1998) is a very readable volume of essays that succeeds in offering more light than heat to illuminate the contentious debate over property rights and the protection of endanger species. The product of research commissioned by the policy board of the Institute for Environment and Natural Resources at the University of Wyoming, the book does present a distinct point of view. The book's foreword and key chapters introduce and support the final chapter's recommendations for ESA reform. The new and improved ESA would engage local stakeholders in collaborative decision-making, provide landowner's flexibility to attain protection goals, create a more favorable climate for implementation (e.g. more certainty for landowners and efficient government oversight), include incentives to spur performance, and promote early intervention to protect habitat. Under the leadership of Interior Secretary Bruce Babbit, changes in these directions are underway, but reformers are looking to ESA reauthorization as an occasion to solidify gains and incorporate new strategies to foster cooperation (p.131).

The drive for ESA reform gains its strength from the basic argument that the law is unfair, benefiting everyone but imposing costs only on a few. But this argument needs to be dressed up to be more persuasive. As a society we maintain many laws that impose unfair burdens. For example, non-drivers must pay taxes that support massive investments in infrastructure used by cars. The book nicely elaborates on the basic argument, providing a solid introduction to private property issues for those new to the subject. With its multi-disciplinary approach, the book has several chapters that should interest more knowledgeable readers. To fully appreciate these complex issues, readers would benefit from additional information regarding the special position of property rights in our country and the strong claims for protection of species. Also one cannot fairly evaluate the book's recommendations for collaborative decision-making without knowing more about the unresolved concerns involving HCPs and other cooperative approaches.

We are introduced to key provisions of the ESA in the book's early chapters that describe the evolution of wildlife protection and the history of ESA interpretation in the courts. The ESA adopts this basic scheme to support recovery of species whose existence is imperiled: listing of species as threatened or endangered, designation of critical habit needed for survival of listed species, protections to prevent extinction, recovery plans to increase population, and de-listing of species no longer at risk. Though not fully appreciated by the law's creators, this scheme puts the ESA on collision course with landowners because listed species depend on private land to survive. In 1993, about 90 percent of the 781 species listed at that time relied on non-federal lands as habitat, and most of that land was in private hands (pp. 1,73).

Section 4 of the ESA outlines the process for designation of "critical habitat," and identifying essential elements needed for survival of species. The designation process, which inevitably sweeps up private landowners, can be viewed as a form of federal zoning limiting future land use. Landowners resent this restriction for reasons that are obvious - it threatens their bundle of rights and options for control -and less obvious - it represents outside control of land use typically reserved for local communities.

Of more immediate concern to property owners are two ESA protections for listed species. The ESA prohibits federal action that is likely to "jeopardize the continued existence" of a listed species or likely to destroy or adversely modify critical habitat. Landowners are trigger federal involvement, for example, by requesting permit approval to fill a wetland for development. Section 7 of the ESA requires that federal agencies obtain a determination called a "consultation" from the Fish and Wildlife Service or the National Marine Fisheries Service. This consultation provides a biological opinion about the impact of the action on a species' survival and includes reasonable and prudent alternatives to avoid adverse impacts.

Section 9 prohibits any person from "taking" any listed animal species, unless they receive a special permit authorizing the "take." The ESA broadly defines a "take" to mean "harass, harm, pursue, hunt, shoot, wound, kill, trap, capture, or collect, or to attempt to engage in any such 
Reviews

conduct." Listed plants have similar protections against destruction and removal. Landowners can run afoul of Section 9 as a result of many activities conducted in the course of agriculture or development (e.g. remove nesting trees or draining wetlands). With a permit issued under Section 10 , landowners can engage in activities that might result in a "taking." A permit is issued based on approval of a Habitat Conservation Plan (HCP) that defines steps to monitor, minimize and mitigate impacts of proposed actions.

The book's middle chapters lay the groundwork for reform based on the limited legal remedies available for ESA restrictions of property rights, questionable effectiveness of the law from a biological standpoint and uncertainties surrounding economic impact of the law. Attorneys Feldman and Brennan correctly observe that landowners cannot depend on the courts to recover compensation under the Fifth Amendment of the Constitution for restrictions imposed by the ESA. Affected landowners will rarely be able to meet the legal requirements designed to cover extreme government actions: a physical invasion onto land (e.g. required installation of bird nesting sites on private land) or a regulation that deprives the owner of all economically viable uses of the property.

Feldman and Brennan point out that landowners have a measure of protection against Fifth Amendment violations because the ESA has internal checks that restrain administrators. It is important to emphasize that these checks are the outgrowth of the political power of landowners. After the US Supreme Court in TVA v. Hill (437 U.S. 153, 184 (1978)), declared that Congress intended the ESA "to halt and reverse the trend toward species extinction, whatever the cost," the opposition pressured Congress to amend ESA several times to take into consideration economic considerations. ESA amendments authorized HCPs to relax restrictions on development and permitted the Secretary to consider economic factors in designating critical habitat. So powerful is their political muscle that the Secretary made concessions to landowners after he won a significant case, Babbitt v. Sweet Home, Chapter of Communities for a Great Oregon, (515 U.S. 687 (1995)), that interpreted the ESA against their interests. In assessing how far we should go in protecting private property in the courts, we should always keep in mind that private property advocates have effective access to the political process to voice their grievances and have the clout to influence outcomes (Sagoff, 1997; 850).

The book's editor Shogren and his colleague Hayward present a series of arguments concerning the ESA that have the effect of shifting of sympathies toward property owners. There is no good way to measure the ESA's biological effectiveness. Measuring obvious indicators such as recovered species suggests that the law is expected to do too much too late. There is no national estimate for the costs imposed on individuals and society by the ESA. How much time and money do landowners spend applying for permits, planning and redesigning projects? What opportunities are lost as a result of ESA restrictions? Are growing government expenditures spent wisely or might they be directed toward more worthy causes? On the other side of ledger, there is no national measure of the economic benefits of the ESA. Economists have trouble measuring the value of an endangered species no one may use or enjoy, and their tools such as contingent valuation yield results open to strong attacks by critics. In fact, the problem of benefits may be worse than Shogren and Hayward portray. The ESA does not protect ecosystems and the services they provide. It is quite possible that we may get these services without protecting individual species (Sagoff, 1997, 844).

Given the many arguments against the ESA, one is left to wonder what justifies protection of endangered species. Shogren and Hayward tell us that economic analysis has no place for moral claims to protect endangered species. But policy decisions are not generated by simply asking economists to plug numbers into equations. As Lockwood suggests in his chapter, moral claims and other non-economic factors play a role. How often have policy makers been influenced by arguments cast in terms of duty and responsibility? One of the most compelling moral arguments follows from our liberal tradition. We as a nation have expanded the circle of those entitled to equal respect and treatment. Women, people of color and disabled persons have received 


\section{Reviews}

protection. Anti-discrimination laws such as the Civil Rights Act subordinated the rights of private landowners to achieve a greater public good. In the case of the Americans with Disabilities Act, private property owners have been required to bear costs to physically accommodate disabled persons. Ever since Aldo Leopold implored us to think of ourselves as part of a larger ecological community, we have been forced to acknowledge our connection to fellow creatures and their moral claim for equal respect and treatment. Viewed in this light, the ESA extends to animals and plants the same right to life and liberty that was slowly secured for marginalized groups such as disabled persons (Nash, 1989: 8).

Whether they speak in terms of equality or ecological services, advocates of protection have staked out strong positions beyond the economic realm. Weighed against property rights, they insist protection of species is the stronger interest. As well as anyone, Bromley $(1998,26)$ makes the case for the subordinate position of property, arguing that it is socially constructed and ought to reflect the changing values of society. When society recognizes that land is critical as habitat, then society can adjust the responsibilities of private landowners without having to pay for additional burdens imposed on individuals. On the other side of the fence, Richard Epstein has forcefully argued for strong protection of property. For Epstein, property occupies the same fundamental position as a natural right as the ecosystem holds for environmental advocates such as Eric Freyfogle (Sagoff, 1997: 836). Society's function is to protect property rights created by private action. When it restricts property rights for the benefit of the public by dedicating land as habitat, society must compensate landowners (Epstein, 1985: 10-11).

It is difficult to conceive of the ESA debate divorced from these strong and irreconcilable positions. Yet this is what Lockwood's chapter challenges us to do. In an effort to locate a middle ground between property and nature protection, he asks us to learn from science, recognizing conflict as a problem of mismatched scales of perception, rather than diametrically opposed philosophies. Whether you can make this leap of faith, this chapter presents an imaginative argument. Those who support the ESA and property owners see the world from different perspectives. The ESA focuses on the long-term interest of single species and habitat protection, while landowners have short-term concerns based on investment and production. Lockwood's answer is to scale down the ESA, implementing the act with attention to the needs of property owners, and scale up property, providing property owners with incentives to account for long-term interests, and expanding notions of property to include public responsibilities.

Turner and Rylander provide concrete examples of flexible measures to close the gap between the social goal of protection and landowner's right of private choice. As part of the expanding use of HCPs, they describe the advent of the "safe harbor" and "no surprises" policies that eliminate penalties and reduce uncertainties for landowners who agree to manage their land to enhance habitat. They highlight conservation agreements that reach landowners who are not engaged in activities that harm listed species and involve them in protection of species that are candidates for listing. Building on these reforms, they envision incentives for landowners such tax relief and tradable habit permits.

HCPs are at the cutting edge of a movement that promises to revolutionize government regulation (Melious and Thornton, 1999: 490; Sabel, Fung and Karkkainen, 1999). Supporters of ESA reform are caught in the energy of this movement, advancing bold plans to build on the success of HCPs. As we plan for the future, we need to look backwards as well as forwards.

A critical examination of HCPs reveals areas that still need improvement. Negotiated management are not rules that are imposed from outside. As the name implies, they are reached by consensus. For every successful negotiation, such as the ground breaking HCP in Southern California, there are more efforts that fall short of the high mark needed for protection. They may end in no agreement, a weak agreement, or a good agreement on paper that is not translated into actions. More research is needed to document successes and failures, and more effort is needed to share such results. Presently, HCPs nationwide can be described as a patchwork of unsupervised and isolated efforts that vary in terms of the quality of performance (Sabel, Fung, and Karkkainen, 1999). 
Reviews

Most importantly, negotiated agreements such as HCPs will struggle for public acceptance without mechanisms for accountability. Anxious about the compromises inherent in negotiated agreements, environmentalists are on guard for lapses in administration that threaten to further undermine protection. Building in accountability does not mean a return to regulation. Proposed legislation such HR 960, the Endangered Species Recovery Act of 1999 offers several fixes to improve performance and accountability, including provisions to insure greater stakeholder participation (Sabel, C., A. Fung, and B. Karkkainen, 1999). For their part, landowners ought to be concerned about accountability. By their nature, these agreements involve complex environmental matters that are in a state of flux. The law protects government's right to change its mind to account for the changing needs of society. Landowners may find they have no recourse to enforce the terms of the original agreement if government changes its position (Melious and Thornton, 1999: 540-1).

While the book's recommendations may increase the incentives and resources to make HCPs effective, they leave much unsaid about these critical questions. We cannot hope to raise a new structure of environmental management if the foundation is weak. It is important that we critically evaluate where we are and how we can shore up what we have. It is unfair to expect this book to have all the answers but it does help us start asking the right questions.

\section{References Cited:}

Epstein, R.

1985. Takings: Private Property and the Power of Eminent Domain. Cambridge; Harvard University Press.

Bromley S.

1998. Rousseau's Revenge: The Demise of the Freehold Estate. In H. Jacobs, ed., Who

Owns America? Social Conflict over Property Rights, Madison: University of Wisconsin Press. pp. 19-28.

Melious J., and R. Thornton.

1999. Contractual Ecosystem Management Under the Endangered Species Act: Can Federal Agencies Make Enforceable Commitments? Ecology Law Quarterly 26: 489-542.

Nash, R.

1989. The Rights of Nature. Madison: University of Wisconsin.

Sabel, C., A. Fung, and B. Karkkainen.

1999. Beyond Backyard Environmentalism: How communities are quietly refashioning environmental regulation. Boston Review 24, 5, available at http:/ /bostonreview.mit.edu/BR24.5/sabel.html (as of February 12, 2000).

Sagoff, M.

1997. Institute Of Bill Of Rights Law Symposium Defining Takings: Private Property And The Future Of Government Regulation: Muddle Or Muddle Through? Takings Jurisprudence Meets The Endangered Species Act. William and Mary Law Rev. 8: 825-993.

Salamon, S.

1998. Cultural Dimensions of Land Tenure in the United States. In H. Jacobs, ed., Who Owns America? Social Conflict over Property Rights, Madison: University of Wisconsin Press. pp. 159-181.

Van de Werf, M.

1995. Endangered Species Act "Gotta Be Fixed," Foe Says. Arizona Republic, 1 July 1995.

Journal of Political Ecology

Vol. 61999 